\title{
The e-Branding in Ecuador and the e-University
}

\author{
Ariana Daniela Del Pino Espinoza, Mga ${ }^{a}$, Lloret-Romero, Nuria, PhD \\ ${ }^{a}$ Escuela Superior Politécnica del Litoral, Guayaquil, Ecuador, ariddel@espol.edu.ec, \\ bUniversitat Politècnica de València, Valencia, España, nlloret@upvnet.upv.es
}

\begin{abstract}
This paper presents an analysis of the 62 universities in Ecuador that are in the web ranking of universities, in order to evaluate the use of digital media and obtain information on the management of university e-branding. The study explores, to a large extent, the digital variables currently used for broadcasting and we include the resources of two indexed databases as a dissemination flow. All this data has been analyzed through statistics and web performance tools. The results indicate the universities in Ecuador do not present a clear use of the academic e-branding as a strategy of dissemination, exposure, and visibility improvement to increase their ranking level. However, it is clear that some have demonstrated the relevance of the uses of these systems to improve their worldwide level spread.
\end{abstract}

Keywords: visibility, university e-branding, Ecuador, universities, social networks, academic networks, professional networks, web

\section{Introduction}

This research paper presents an analysis of the level of visibility maintained by public and private universities in Ecuador from the point of view of university e-branding. The study covers all digital spaces and the level of impact among its users, highlighting the differences in the system of use. This article focuses on studying and analyzing the visibility of e-branding of universities in Ecuador.

Some universities worldwide have implemented digital university branding strategies to improve visibility in the digital space, a focused model that can be applied and that adapts over time to the new technological changes has not been created. Two relevant studies developed in British (Chapleo, Carrillo Durán, \& Castillo Díaz, 2011) and Spanish universities, has shown that in Europe, the universities are adjustingto the digital changes, but these studies only analyze the functional values ("related to education and research activities, than to values of an emotional nature"), and emotional ("highlighting among 
them the commitment to the international projection of their brands.") of the websites (Castillo Díaz, Carrillo Durán, \& Tato Jiménez, 2013). Acosta and Luján have carried out a study of the accessibility to the websites of Ecuadorian universities, evaluated 44 universities of the existing ones where they analyzed the level of accessibility, the errors, and compliance with INEN regulations. (Acosta \& Luján-Mora, 2017:47-48).

In the article presented by Del Rio, Cardona and Simancas, a branding model is proposed to position university brands, where it describes what "the value of organization and reputation" represents, which must be taken into account by the public and the setting (Del Rio-Cortina, Cardona-Arbelaez, \& Simancas-Trujillo, 2017: 40), aspects that are built over time.

The disproportionate growth of the use of digital media among higher education institutions has changed the way we teach, learn, and present themselves to the world, using new terms asociated to digitalisation, as e-Universities are defined as digital education, from the computer science revolution point of view, through the network and digital attention that allows processes or procedures, and even allows to virtual or online studies under the supervision of a tutor; e-Communication refers to the term on any form of computermediated communication and more traditional forms of electronic communication, such as telephone communication (Kock, 2001: 3); even e-Science, which involves the collaborative use of geographically distributed resources interconnected through the Internet (García Álvarez \& López Sintas, 2012: 500), among others. This is why we find the use of the Internet as a mediatic and now didactic resource a priority. The university achievements, reseach and publications found a wide space in electronic media, the eScience is also understood as the set of scientific activities developed by the use of distributed resources accessible through the internet (Fecyt, 2004).

\subsection{University e-Branding}

The e-branding, digital branding, internet branding or online branding, according to Rowles in his book Digital Branding explains what the whole personality of the organization is what includes the services or products, under the sum of the experiences from the point of visual identity with the interaction in social networks and the criticisms it has online, even more by the sum of the generated value (Rowles, 2014:344). According to Adamson in his book BrandDigital says that to understand digital technology you must interact with it, which has its own learning curve. It is not enough to read articles about the evolution of the internet to get your brand right, to provide value to the consumers with whom you want to do business, it is essential to know the areas where they and your brand are managed (2008:274). Both authors take for settled that it is important to know everything that surrounds the brand in the digital aspect and what is spoken about it. 
The university has changed by taking into account the importance of the cognitive and affective aspects within the brand management (Beerli Palacio, Díaz Meneses, \& Pérez Pérez, 2002:491). The optimization and creation of websites, search of social media on the web (Jansena, Sobelb, \& Zhangc 2011:79), blogs, digital press releases, and marketing videos are all methods used for the digital Branding process (Green, R. 2013) (Fallon, N. 2013).

Thus, the concept of University e-Branding was raised, indicating it to be everything which the university implements to transcend in the digital sphere from the academic, scientific and professional; involving several stakeholders, be these teachers, students, researchers, guests, among others, and this way, increase the interaction of researchers, students and others, creating an environment conducive to ally even with companies, and generate a convenient context for a better scientific-research-business development.

The University e-Branding that includes the management of the business and academic brand is related to the scientific research levels, which the university shares through various physical and digital-interactive spaces to disseminate new discovered knowledge, statistics, and others. It improves the student-university educational experience. Also, it uses multiple strategies to reach students, and is built with the reputation generated by academics, students and their research through the network as a platform for integration and dissemination.

\subsection{Digital Aspects}

Although there are different options for evaluating digital resources, and as Codina considers, it plans a series of parameters and indicators of digital resources that study web quality (Codina, 2000, págs. 21-24), accessibility (Buenadicha, Chamorro Mera, Miranda González, \& González López, 2002:106), browsing (Thelwall \& Aguillo, 2003:293), competition with strategies approaches in terms of business (Kotler, Kotler, \& Kotler, 2008) and lastly, its international image and brand strategies (Gray \& Fam, 2003). This research clarifies the horizons for the analysis of the visibility of higher education institutions through the Internet, resources that have not been put into consideration to understand how the e-Branding of certain universities is displayed on the network.

\section{3. e-University}

University education worldwide is changing the system to teach and instruct classes, partly due to technological advances and the flow of information found on the Internet. The use of electronic devices, the initiative of virtual classrooms and 2.0 or virtual environments (Aguirre Andrade \& Manasía Fernández, 2009:322), have undoubtedly led to the 
development of scientific fields of research application in this area. Ellin proposes the idea that the university is entrepreneurial, maintains many traditional characteristics, but in the 21 st century, innovation, creativity and the initiative of individual self-learning have allowed to create a new space and a new way of learning. A digital university is one that pretends to be autonomous, communicates with the community, trains leaders and people of power, who are cultivated outside the classrooms, libraries or laboratories. (Ellin, 2006:4).

Among the aspects that the university brand image must communicate, we find the cognitive, rational, functional and affective or emotional dimensions; therefore, the attributes of the institution must be transmitted in an appropriate way (Beerli Palacio, Diaz Meneses, \& Perez Perez, 2002:489). Murphy defines that "The management of the brand consists of the development and maintenance of a series of attributes and values of the product, which are coherent, appropriate, distinctive, projectable and attractive to consumers" (Murphy \& Rowe, 1992).

University Co-Branding is achieved in scientific events such as conferences or presentations, cooperation between universities is very common to share expenses, present research together and show results. The use of pairs between universities also generates a greater emphasis on scientific articles.

This research proposal allows us to know the usage level of online university branding in Ecuador, we will evaluate the uses of current digital resources such as: web pages, social networks, academic social networks, professional social networks, university rankings, Google Scholar usage, Search index in Google Trends, publications in Database such as ISI Web of knowledge and Scopus, use of technological resources for their classes such as virtual reality, virtual classrooms and MOOC.

This paper attempts to achieve the objective of analyzing the current management state of universities academic e-branding in Ecuador, both public and private, to create a proposed method of analysis of e-branding for higher education institutions.

\subsection{Research Query}

- Do the creation years affect the growth of the university's digital or research space?

- Do digital profiles or online interaction allow a better flow of communication with their users?

- Do the websites of the universities in Ecuador maintain optimum performance for the users' use? 


\section{Method}

The study will take into account $100 \%$ of the population, the 62 public and private Ecuadorian universities, 31 are public universities and 32 are private, one of them doesn't have a website, in figure 1 you can see the list. Using a decriptive methodology, we evaluate the digital resources of the study subjects on the use of e-branding level, with a quantitative and qualitative approach through the construction of indicators explained through phases.

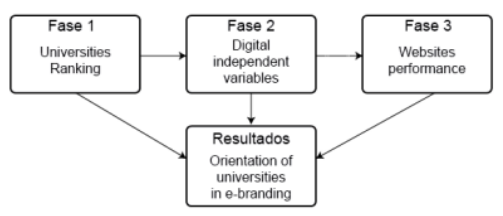

Figure. 1 Research Model

The phases applied for this analysis are the following:

1. Analysis of its positioning in the rankings of Latin America (QS World University Rankings) and web (Ranking web of universities), locating the level of universities in Ecuador, the other rankings were not considered when not including Ecuadorian universities. The rankings determine the level that the universities occupy among themselves, and how important they are in the country.

2. The variables that will be evaluated independently are: a. Age (knows the level of influence by the creation years); b. Google Scholar (academic profiles as a broadcast medium); c. Use of database (wok/scopus, to know the universities' academic publication level); d. Use of social, academic and professional networks (user level to understand the interaction with the information flow).

3. Web use management: a. Functionality; b. Ergonomics, using observation and GTmetrix we will obtain data on the percentage and level of performance and optimization (necessary for circulating relevant institutional, student and academic information).

With the data obtained in the second point, we will determine how influential these universities can be online. For the data obtained in the websites, it will be taken into account frequency of exposure level, usability, and visual reinforcements. In the end, we will be able to establish the universities by the awareness level of need for the use of university e-branding and expose relevant data that could be included in the future, where no type of university, private or public, will be discriminated. 


\section{Results and Discussion}

Through the proposed research, we have managed to learn the scope of the management of digital academic branding in certain areas. In each of the phases, greater contributions could be determined with a greater interaction analysis.

Fase 1 - In the positioning analysis we find the following results:

Ranking web of universities, makes visible all those universities that have a digital space and by level of use, for which, we will find all the universities mentioned above, we find 62 universities.. (Webometrics, 2018)

Latin American Ranking (QS World University Rankings) evaluates the existing universities by country that maintain a level of publication, world reputation, among others, in this ranking we find only 12 and within these 12, 4 of them are from Guayaquil, 6 from Quito, 1 from Cuenca and 1 of Azuay, the other universities are not in the aforementioned ranking. There are no universities in the other rankings therefore it was not included in the research, or for the moment, they have not managed to enter. (Quacquarelli Symonds Limited, 2018)

Fase 2 - In the analysis of the independent variables, they have been divided as follows:

1. Grupo 1 Age.

2. Grupo 2 Google Scholar, academic and social networks.

3. Grupo 3 Publications database.

4. Grupo 4 Social and professional networks.

For group 1, an average of the universities age was made, considering if it influences their positioning and discovery, also, if this influences in any way in their mode of interaction with the digital university branding. The average age of the universities is 46 , which indicates that among all the universities there is a close relationship because their standard deviation is 52.29. A total of 52 universities are in a ranking less than 50 years, the Universidad Central del Ecuador is the eldest with 367 years, and does not maintain a flow of Twitter, Instagram and YouTube, and even less a large flow of articles published in WOS / SCOPUS, but with a strong presence on Facebook and Linkedin.

In group 2 shown in figure 2, we see the interaction of Google Scholar and academic social networks (researchgate, academia.edu). Private universities have shown a lesser use of these tools, they do not achieve a great propagation of their scientific production and it is low in comparison with universities worldwide. $68 \%$ of public universities do not use Google Scholar, unlike private universities, which do not reach $71 \%$ of use. Most of the universities showed that the most used platform is researchgate, after academia.edu and, 
finally, Google Scholar, which has less importance of use, being a support platform to share articles and/or books, etc.

The average is 874 , which indicates that among all universities there is a close relationship because its standard deviation is 1236.62 . The university with the highest number of users in researchgate is ESPOL (public) with 2109, while in academia.edu, we find UCE (public) with 3551 users, finally, just as important for its level of search, Google Scholar, we found UPS (private) with 502 users, very low levels of interaction..

In group 3, as shown in figure 2, we investigated the number of publications in two of the most used databases in Ecuador, unlike private universities, 87 and $90 \%$ do not have more than 250 publications, contrary to the case of private with 61 and $77 \%$. The two universities with the highest percentages were PUCE (private) with 400 and USFQ (private) with 1,430 publications, which indicates that private universities are betting on scientific production which leads to the production of articles. The average is 196, which indicates that among all universities there isn't a very close relationship because their standard deviation is 315.70 ..

In group 4 shown in Figure 2, we will check the level of broadcast universities have with respect to the followers flow. It is clear that the private universities have taken into greater consideration the use of social media, who have managed to attract more followers and manage to disseminate their events, connecting with students, but there are still a number of universities that do not have social media profiles or they do not give them an adequate management, they are not even linked in their websites for easy access, and lastly, they do not have the same nomenclature in most of their accounts. The average is 93.68, which indicates that among all universities there is no close relationship because its standard deviation is $151,019.63$.

In these five social networks, we have USFQ (private) as the university with the most followers on Facebook, with 895,903, likewise on their Twitter account with 74,500, on Instagram the university with the largest followers is UDLA (private) with 20,900, while Youtube and Linkedin are of greater affluence in public universities, with 42,000 for ESPOL and 56,760 for UG, consecutively. 


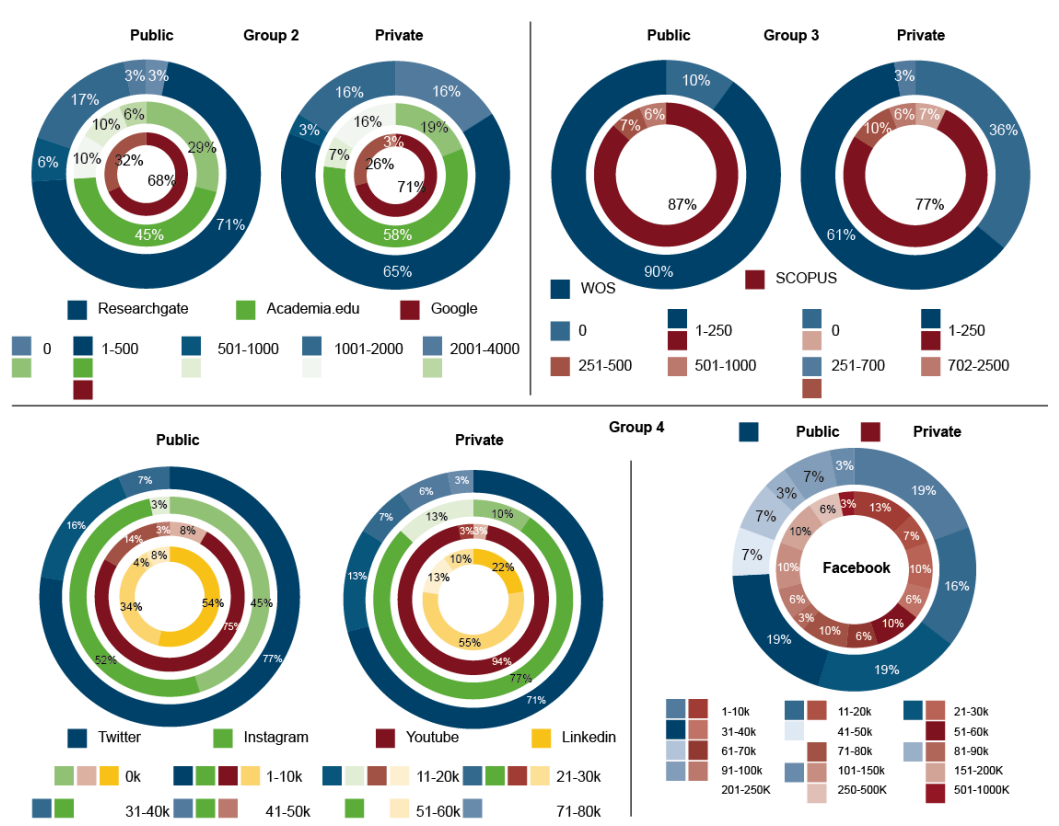

Figure 2. Academic Social Networks, Google Scholar, Database Publications, Social Networks and Professional Social Networks

Source: Google Scholar (2018), Researchgate (2018), Academia.edu (2018) Scopus (2018), Web of Knowledge (2018), Facebook (2018), Twitter (2018), Instagram (2018), Youtube (2018), Linkedin (2018)

Fase 3. Web analysis, operational levels, and optimization

Thirdly, on the implementation of the websites, two analyses were conducted: the operational and optimization level, and the performance.

Average performance. Functionality and optimization levels

31

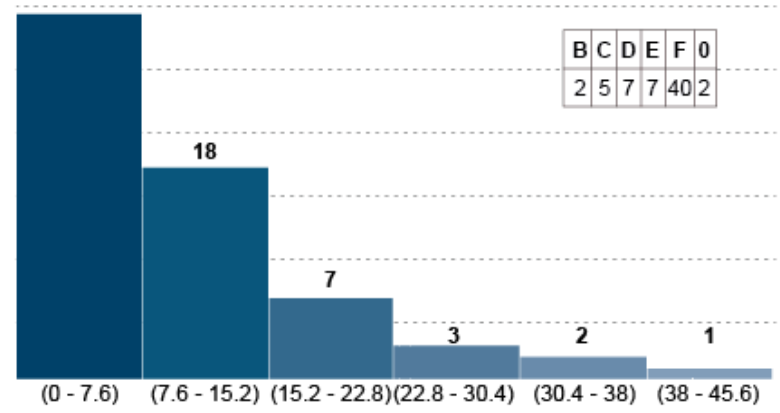

Figure 3. Average performance. Functionality and optimization levels.

Fuente: GTmetrix (2018) 
Through the use of the GTmetrix tool (GT.net, 2018), which allows to know the performance failures of the websites of the universities, two universities could not be analyzed by the tool, IAEN (public) and UTI (public ). Websites are the face of the university, where you can learn all the services offered to the public, as well to the university community. The universities with a better optimization were UCE (public) and UCT (public), but it was not the same case for the performance and load of the UNIBE (private) site that presented a better option with a percentage of $1.2 \mathrm{~s}$ of response compared to all the other 61 sites. The average is 10.44 , which indicates that among all universities there is a very close relationship because its standard deviation is 8.61 .

Therefore, this research was able to determine that the use of digital academic branding or academic e-branding, is not being used in all universities to a large extent, which could favor the communication flow of universities for better interaction performance, but is clear that universities in Ecuador are very far from this management tasks, although some have shown that the use of these media work and improve areas such as image and ranking.

A clear example is the case of USFQ, and the most notorious of the 62, which is in a good position in the ranking, but taking into account the deficiencies found, could improve its academic e-branding and increase its visibility to ranking and users of a global scale, it could be taken into account the relevance of academic e-branding and would function as a scientific-academic system.

With the results obtained, the research questions are answered:

Of the 62 universities, only 3 exceed 100 years, and they do not rank high in the ranking. The years of creation do not totally inflate the performance of universities to improve visibility, nor positioning in the network, but it is a point of support to show all those processes that have been carried out since its inception, it can also show that universities have not evolved with the pace of trends and new generations.

The universities demonstrated that they do not show relevant information and, in many cases, was difficult to know if they have social, academic and professional networks on their website, you can even use the website as a record of their teachers' information, awards and recognitions, progress or relevant discoveries and publications. $40 \%$ did not present the years of seniority on their website, which made it difficult to search.

40 of the 62 universities demonstrated an F performance with a record low speed per load, just as the load time an average of 31 universities maintains more than 8 
seconds as a complete visualization response. Therefore, it is low level of performance, operation and optimization.

\section{Conclusion}

Through this analysis, an attempt was made to determine if there is a management of university digital branding within Ecuador, besides being considered as a methodological proposal to analyze the performance of e-branding for higher education institutions. It is evident that private universities are even more concerned about the dissemination of all the actions they carry out, both scientific, academic, student and management, among others; therefore, they could end up advertising, unlike public universities, which have not seen the potential of using social networks as a means of dissemination and collaboration between different universities worldwide.

Education, in institutions of higher education, has made it clear that it must change, and initiate an investigation of the future, new and current needs more important, nationally and globally, transforming the context of education into a new tide of technical-practical concepts. An analysis of this magnitude makes it possible to assess which are the parameters in which the institutions fail to understand the level of visibility. It is suggestive that, in both cases, they renew the necessary relevant information on the websites, to publicize merits, articles, books, awards, student life, graduates and outstanding professors.

Encourage the use of platforms that search engines move and generate more information traffic, and increase a standard format for each university on the management of academic e-branding. It was not possible to find information about the use of virtual reality or virtual classrooms for the public, something that can contribute to the benefit of students and the community in a better and faster complementary learning. The university entity should be a tourism agent, as a scientific, educational, and can generate greater impacts in a positive way towards the community. It can include, afterwards, a research and evaluation of the frequency variables of publication of social networks and the valuation by teachers as university referents, through its digital branding, academic staff, and even include the level of influential students that contribute to add to the universities. 


\section{References}

Acosta, T., \& Luján-Mora, S. (Febrero de 2017). Análisis de la accesibilidad de los sitios web de las universidades ecuatorianas de excelencia. Enfoque UTE, 7, 46-61.

Adamson, A. (2008). Branddigital: simple ways top brands suceed in the digital world. New York: Palgrave Macmillan.

Aguirre Andrade, A., \& Manasía Fernández, N. (2009). Web 2.0 y Web semántica en los entornos virtuales de aprendizaje Multiciencias. Multiciencias, 9(3), 320-328.

Beerli Palacio, A., Diaz Meneses, G., \& Perez Perez, J. (2002). The configuration of the university image and its relationship with the satisfaction of students. Educational Administration, 486-505.

Beerli Palacio, A., Díaz Meneses, G., \& Pérez Pérez, P. (2002). The configuration of the university image and its relationship with the satisfaction of students. Journal of Educational Administration, 40(5), 486-505.

Buenadicha, M., Chamorro Mera, A., Miranda González, F., \& González López, Ó. (2002). Las universidades españolas en el World Wide Web: aplicación de un nuevo índice de evaluación. de sitios web. Obtenido de Cepade n 27: http://www.cepade.es/Ademas/revista.asp?numero=27\#\#\#\#

Castillo Díaz, A., Carrillo Durán, M. V., \& Tato Jiménez, J. L. (2013). Branding online en las universidades españolas. Análisis de los valores funcionales y emocionales en sus websites corporativos. Estudios sobre el Mensaje Periodístico, 19(especial marzo), 85-97.

Chapleo, C., Carrillo Durán, M. V., \& Castillo Díaz, A. (2011). Do UK universities communicate their brands effectively through their websites? Journal of Marketing for Higher Education, 21(1), 25-46.

Codina, L. (2000). Parámetros e indicadores de calidad para la evaluación de recursos digitales. 7as Jornadas españolas de documentación, 135-144.

De Chernatony, L., Dall Olmo Riley, F., \& Harris, F. (1998). Criteria to assess brand success. Journal of Marketing Managment, 765-781.

Del Río Cortina, J., Cardona-Arbelaez, D., \& Simancas-Trujillo, R. (2017). Propuesta de un modelo teórico de branding para el posicionamiento de la marca universitaria. Espacios, 38(53), 34-47.

Ellin, J. (2 de January de 2006). Introduction: The Entrepreneurial University. En C. o. University, Universities and Corporations. A selection of papers presented at the WMU Emeriti Council Forum (Vol. XVI, pág. 86). Michigan: Center of the Study of Ethics in Society Western Michigan University.

Fallon, N. (10 de diciembre de 2013). Why Online Brand Management Matters (Even Offline). Obtenido de Business News Daily: http://www.businessnewsdaily.com/5590-online-brandmanagement-tips.html 
Fecyt. (2004). Libro blanco e-Ciencia en España 2004. Recuperado el enero de 2018, de Fundación Española para la Ciencia y la Tecnología: https://www.fecyt.es/es/publicacion/libro-blanco-eciencia-en-espana

Fecyt. (2004). Libro blanco e-Ciencia en España 2004. Recuperado el July de 2017, de Fundación Española para la Ciencia y la Tecnología: https://www.fecyt.es/es/publicacion/libro-blanco-eciencia-en-espana

García Álvarez, E., \& López Sintas, J. (2012). Ciencia abierta, e-ciencia y nuevas tecnologías: Desafíos y antiguos problemas en la investigación cualitativa en las ciencias sociales. Intangible Capital, 497-519.

Gray, B. J., \& Fam, K. S. (2003). Branding universities in Asian markets. Journal of Product \& Brand Management, 12(2), 108-120.

Green, R. (25 de Junio de 2013). 7 Highly-Effective Ways to Maximize Your Online Brand Presence. Obtenido de The Huffington post: http://www.huffingtonpost.com/r-kay-green/online-brandpresence_b_3140951.html

GT.net. (2018). GTmetrix. Obtenido de GTmetrix: https://gtmetrix.com/

Jansena, B., Sobelb, K., \& Zhangc, M. (2011). The Brand Effect of Key Phrases and Advertisements in Sponsored Search. International Journal of Electronic Commerce, 6, 77-106.

Kock, N. (2001). The Ape that Used E-Mail: Understanding E-Communication Behavior Through Evolution Theory. Communications of the Association for Information Systems, 5, 1-29.

Kotler, N., Kotler, P., \& Kotler, W. (2008). Museum strategy and marketing: Designing missions, building audiences, generating revenues and resources. San Francisco: Jossey-Bass.

Murphy, J., \& Rowe, M. (1992). Como diseñar marcas y logotipos (Vol. 3). Barcelona: Gustavo Gili.

Quacquarelli Symonds Limited. (2018). QS TOP UNIVERSITIES. Obtenido de QS World University Rankings 2018: https://www.topuniversities.com/university-rankings/world-universityrankings $/ 2018$

Rowles, D. (28 de Abril de 2014). Digital Branding - A complete step-by-step guide to strategy, tactics and measurement. London, England.

Thelwall, M., \& Aguillo, I. (2003). La salud de las webs universitarias españolas. Revista Española de Documentación Científica, 26(3), 291-305.

Universidad de Cuenca. (2018). Nosotros: Universidad de Cuenca. Obtenido de Universidad de Cuenca: https://www.ucuenca.edu.ec/sobre-la-udc\#historia

Webometrics. (2018). Ecuador: Ranking web of universities. Obtenido de Ranking web of universities: http://webometrics.info/en/Latin_America/Ecuador 